\title{
RANCANG BANGUN ALAT PRAKTIKUM TURBIN AIR DENGAN PENGUJIAN BENTUK SUDU TERHADAP TORSI DAN DAYA TURBIN YANG DIHASILKAN
}

\author{
Ahmad Yani \\ Jurusan Teknik Mesin Fakultas Teknik Universitas Trunajaya Bontang \\ Jl. Taekwondo No. 55 RT. 09 Kelurahan Api - Api Bontang - Kaltim 75311 \\ Email: yanibima@gmail.com
}

\begin{abstract}
Abstrak
Turbin air adalah salah satu mesin penggerak yang mana fluida kerjanya adalah air yang dipergunakan langsung untuk memutarkan roda turbin. Penelitian ini dilakukan dengan menggunakan instalasi turbin air jenis pelton dan dilakukan pengukuran terhadap gaya, putaran dan debit aliran dengan variasi bentuk sudu. Metode penelitian yang digunakan adalah metode eksperimen dengan rancangan percobaan berskala laboratorium sekaligus hasil rancang bangun turbin air ini digunakan sebagai alat praktikum mahasiswa jurusan teknik mesin. Hasil penelitian menunjukan adanya pengaruh bentuk sudu terhadap torsi dan daya turbin yaitu Torsi turbin maksimum terjadi pada sudu sendok sayur dengan nilai sebesar 0,555 Nm, kemudian torsi kedua pada sudu datar dengan nilai sebesar $0,435 \mathrm{Nm}$, torsi ke tiga pada sudu setengah silinder dengan nilai sebesar $0,420 \mathrm{Nm}$, torsi keempat pada sudu sendok nasi dengan nilai sebesar 0,375 Nm, dan torsi terendah terjadi pada sudu lengkung dengan nilai sebesar 0,360 $\mathrm{Nm}$. Sedangkan daya turbin maksimum terjadi pada sudu sendok sayur dengan nilai sebesar 5,652 Watt, kemudian daya turbin tertinggi kedua terjadi pada sudu sendok nasi nilai sebesar 5,024 Watt, urutan daya turbin tertinggi ketiga terjadi pada sudu lengkung dan pada sudu setengah silinder nilai sebesar 4,082 Watt, sedangkan daya turbin terendah terjadi pada sudu datar nilai sebesar 3,297 Watt.
\end{abstract}

Kata Kunci : Rancang bangun, turbin air, bentuk sudu, torsi, daya turbin.

\section{Pendahuluan}

Turbin air adalah salah satu mesin penggerak yang mana fluida kerjanya adalah air yang dipergunakan langsung untuk memutarkan roda turbin. Pada roda turbin terdapat sudu dan fluida kerja mengalir melalui runag di antara sudu tersebut. [1]

Turbin pelton merupakan turbin impuls, yaitu turbin yang digerakkan oleh energy kinetic air. Semprotan air yang bercecepatan tinggi mengenai sudu dan setelah menggerakkan runner air keluar pada kecepatan rendah, yang berarti sebagian energinya tidak diserap oleh runner.
Tekanan air masuk dan keluar sudu adalah tekanan atmosfir. [2]

Laboratorium merupakan tempat untuk melatih mahasiswa dalam hal keterampilan melakukan praktek, demonstrasi, percobaan, penelitian dan pengembangan ilmu pengetahuan. Keberadaan laboratorium sebagai tempat praktikum sangat diperlukan untuk meningkatkan ketrampilan mahasiswa. Pelaksanaan kegiatan praktikum dilakukan dalam pemberian pengalaman belajar kepada mahasiswa, supaya mahasiswa dapat berinteraksi dengan bahan - bahan pelajaran dan pengamatan gejala secara langsung 
yang terjadi pada alat uji turbin air tersebut. Kegiatan praktek di laboratorium dapat meningkatkan keterampilan mahasiswa apabila digunakan secara efisien, karena dengan praktek mahasiswa dapat memahami mata kuliah yang memerlukan penghayatan kongkrit dengan melakukan kegiatan nyata melalui praktek. [3]

Jurusan Teknik Mesin Universitas Trunajaya Bontang sudah berdiri sejak Tahun 1990, namun keberadaan laboratorium, sarana dan prasarana praktikum mahasiswa sampai sekarang masih minim, padahal sarana dan prasarana praktikum yang ada dilaboratorium sangat mendukung dalam mempraktekkan konsep yang telah dipelajari mahasiswa untuk meningkatkan prestasi belajarnya, terutama pada matakuliah turbin air yang penulis ajarkan. Turbin air yang penulis buat ini untuk alat praktikum mahasiswa, turbin ini merupakan jenis turbin impuls yaitu pelton.

Penelitian terdahulu pada Tahun 2016 yang telah dilakukan oleh penulis tentang kinerja turbin air kinetik poros vertikal. \{yani\} Penelitian lanjutan ini diharapkan dapat menjelaskan bagaimana unjuk kerja dari prototype turbin air pelton yang telah dibuat apabila menggunakan variasi bentuk sudu turbin. Bentuk sudu turbin sangat menentukan putaran turbin sehingga dapat meningkatkan daya turbin. Untuk itu maka penelitian ini diarahkan untuk menentukan bentuk sudu yang tepat untuk menghasilkan daya turbin yang maksimal.

\section{Tinjauan Pustaka}

Turbin air adalah merupakan mesin penggerak yang merubah energy potensial menjadi energy mekanik dengan air sebagai fluida kerjanya. Menurut sejarahnya turbin hidrolik sekarang berasal dari dari kincir kincir air pada jaman abad pertengahan yang dipakai untuk memecah batu bara, keperluan pabrik gandum, dan lain - lain. [4]. Berdasarkan perubahan energi turbin air dibedakan menjadi dua kelompok yaitu turbin impuls dan turbin reaksi.

\section{Turbin impuls}

Turbin impuls disebut juga dengan turbin air tekanan sama karena tekanan air yang keluar dari nossel tekanannya sama dengan tekanan atmosfir sekitarnya. Sehingga energi tempat dan energi tekanan yang dimiliki oleh aliran air dirubah semuanya menjadi energi kecepatan. Contoh dari turbin impuls ini adalah turbin pelton yang merupakan jenis turbin yang dibuat menjadi objek penelitian penulis. [6]

Turbin air pelton adalah sebuah alat berbentuk lingkaran yang dibangun di sungai yang mempunyai debit air kecil tetapi mempunyai head yang tinggi. Alat ini berputar pada sumbunya karena adanya dorongan aliran air melalui pipa pesat yang cukup cepat. Sejalan dengan berputarnya turbin, alat ini sekaligus mengambil air dari sungai dan ditampung dalam sebuah bak penampung, selanjutnya dialirkan melalui sebuah pipa pesat dan dikeluarkan melewati sebuah nossel. [6]

\section{Turbin Reaksi}

Turbin Reaksi adalah turbin yang memanfaatkan seluruh energi (energi Potensial, kinetik dan tekanan) untuk menghasikan energi kinetik di sudu. Sudu pada turbin reaksi mempunyai profil khusus yang menyebabkan terjadinya penurunan tekanan air selama melalui sudu. Perbedaan tekanan ini memberikan gaya pada sudu sehingga runner (bagian turbin yang berputar) dapat berputar. Turbin yang bekerja berdasarkan prinsip ini dikelompokkan sebagai turbin reaksi. Runner turbin reaksi sepenuhnya tercelup dalam air dan berada dalam rumah turbin. 
pada pengujian turbin air hasil yang diharapkan adalah mendapatkan daya turbin. [5]

Proses perhitungan dengan mengunakan persamaan berikut :

Luas Penampang ujung nosel (A)

Persamaan untuk menghitung luas ujung nosel yang menumbuk sudu turbin digunakan persamaan 1 :

$$
A=\frac{1}{4} \cdot \pi \cdot d^{2}
$$

Dengan:

$$
\begin{aligned}
& \mathrm{A}=\text { Luasan ujung nosel }\left(\mathrm{m}^{2}\right) . \\
& \mathrm{D}=\text { diameter dalam nosel }(\mathrm{m})
\end{aligned}
$$

Kapasitas Aliran (Q)

Untuk menghitung kapasitas aliran, digunakan persamaan 2 :

$$
Q=A \cdot V
$$

Dengan:

$$
\begin{aligned}
& Q=\text { Debit aliran air }\left(\mathrm{m}^{3} / \mathrm{s}\right) . \\
& \text { A }=\text { Luasan ujung nosel }\left(\mathrm{m}^{2}\right) . \\
& v=\text { Kecepatan aliran }(\mathrm{m} / \mathrm{s}) .
\end{aligned}
$$

Kecepatan Aliran (V)

Untuk menghitung kecepatan aliran, digunakan persamaan 3:

$$
V=\frac{Q}{A}
$$

Laju Massa Air yang Mengalir $(\dot{m})$

Massa aliran digunakan persamaan 4:

$$
\dot{m}=\rho \cdot Q
$$

Dengan:

$$
\begin{aligned}
\dot{m} & =\text { Laju aliran massa air }(\mathrm{kg} / \mathrm{s}) \\
\rho & =\text { Massa jenis air }\left(\mathrm{kg} / \mathrm{m}^{3}\right) . \\
Q & =\text { Debit aliran air }\left(\mathrm{m}^{3} / \mathrm{s}\right) .
\end{aligned}
$$

Daya Air yang Mengalir $\left(\mathrm{P}_{\mathrm{a}}\right)$

Daya air dapat dihitung dengan mempergunakan persamaan 5 :

$$
P_{a}=\frac{1}{2} \rho \cdot A \cdot V^{3}
$$

\section{Dengan:}

$$
\begin{aligned}
& \mathrm{P}_{\mathrm{a}}=\text { Daya air }(\text { Watt }) . \\
& \rho=\text { Massa jenis air }\left(\mathrm{kg} / \mathrm{m}^{3}\right) .
\end{aligned}
$$

$$
\begin{aligned}
A= & \text { Luasan saluran air pada ujung } \\
& \text { nosel turbin }\left(\mathrm{m}^{2}\right) . \\
v= & \text { Kecepatan aliran }(\mathrm{m} / \mathrm{s}) .
\end{aligned}
$$

\section{Torsi Turbin ( $\mathrm{T}$ )}

Besarnya torsi dapat dihitung dengan persamaan 6:

$$
T=F . R
$$

Dengan :

$$
\begin{aligned}
& \mathrm{T}=\operatorname{torsi}(\mathrm{Nm}) \\
& \mathrm{F}=\text { Gaya pembebanan }(\mathrm{N}) \\
& \mathrm{R}=\text { Jari }- \text { jari pully }(\mathrm{m})
\end{aligned}
$$

Kecepatan Anguler $(\omega)$

Untuk mendapatkan nilai kecepatan anguler menggunakan persamaan 7 :

$$
\omega=\frac{2 . \pi \cdot n}{60}
$$

Dengan :

$$
\begin{aligned}
\omega & =\text { Kecepatan Anguler }(\mathrm{rad} / \mathrm{s}) \\
\mathrm{n} & =\text { Putaran turbin }(\mathrm{rpm})
\end{aligned}
$$

Daya Turbin $\left(\mathrm{P}_{\mathrm{t}}\right)$

Daya turbin dihitung dengan menggunakan persamaan 8:

$$
P_{t}=T . \omega
$$

Dengan :

$$
\begin{aligned}
& P_{t}=\text { Daya turbin }(\text { Watt }) \\
& \mathrm{T}=\text { torsi }(\mathrm{Nm}) \\
& \omega=\operatorname{Kecepatan} \text { Anguler }(\mathrm{rad} / \mathrm{s})
\end{aligned}
$$

\section{Metode Penelitian}

Penelitian yang dilakukan menggunakan metode eksperimental dengan rancangan percobaan berskala laboratorium menggunakan satu set up peralatan turbin air jenis impuls pelton dan metode pengambilan data dengan cara pengereman putaran turbin atau metode pemberian beban gaya pada putaran turbin seperti ditunjukkan pada gambar 7. Penelitian ini bertempat di Laboratorium Jurusan Teknik Mesin Fakultas Teknik Universitas Trunajaya Bontang dan waktu penelitian dilakukan pada Bulan Maret 2017 dengan pengujian bentuk sudu turbin yang digunakan pada alat praktikum turbin air yang penulis rancang 
seperti ditunjukkan pada gambar 1 sampai gambar 5 dan set up peralatan penelitian ditunjukkan pada gambar 6 dengan ukuran alat penelitian yaitu panjang $110 \mathrm{~cm}$, lebar $60 \mathrm{~cm}$, dan tinggi $40 \mathrm{~cm}$ yang terbuat dari besi plat siku. Ukuran bak penampung air sebesar $60 \mathrm{~cm}$ x $60 \mathrm{~cm}$ yang terbuat dari lembaran plat besi dengan ketebalan $0,3 \mathrm{~cm}$. sedangkan ukuran runner turbin berdiameter $21,5 \mathrm{~cm}$ yang terbuat dari piringan rem cakram sepeda motor. Sedangkan ukuran poros turbin berdiameter $2,54 \mathrm{~cm}$ dengan panjang $80 \mathrm{~cm}$.

\section{Variabel Penelitian}

Variabel yang digunakan pada penelitian ini ada tiga yaitu variabel bebas, variabel terikat dan variabel terkontrol.

a. Variabel Bebas

Variabel bebas pada penelitian ini terdiri dari:

1. Debit air : $0,0005 \mathrm{~m}^{3} / \mathrm{s}$

2. Bentuk sudu diantaranya: sudu datar, sudu lengkung, sudu setengah silinder, sudu sendok nasi, dan sudu sendok sayur. Bentuk sudu turbin yang digunakan seperti ditunjukkan pada gambar 1, 2, 3, 3, dan 5 .

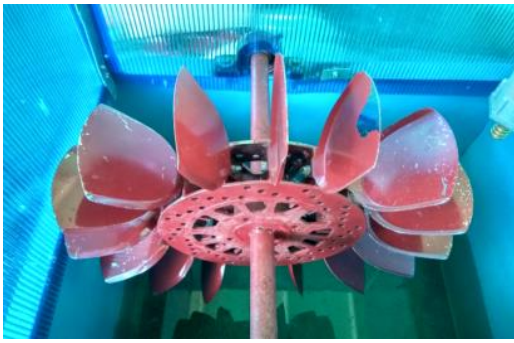

Gambar 1. Bentuk sudu datar.

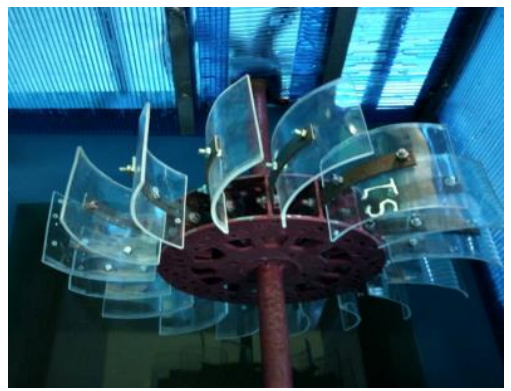

Gambar 2. Sudu lengkung.

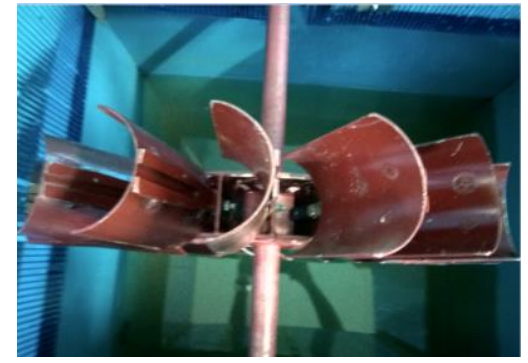

Gambar 3. Sudu setengah silinder.

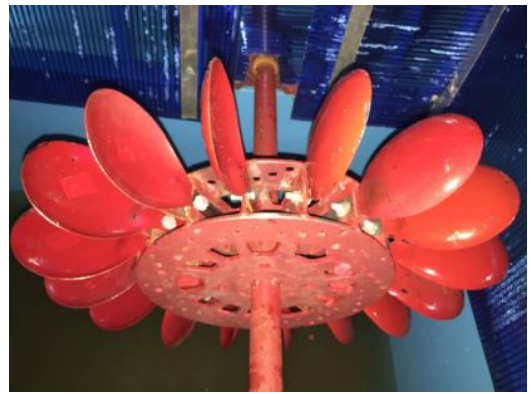

Gambar 4. Sudu sendok nasi.

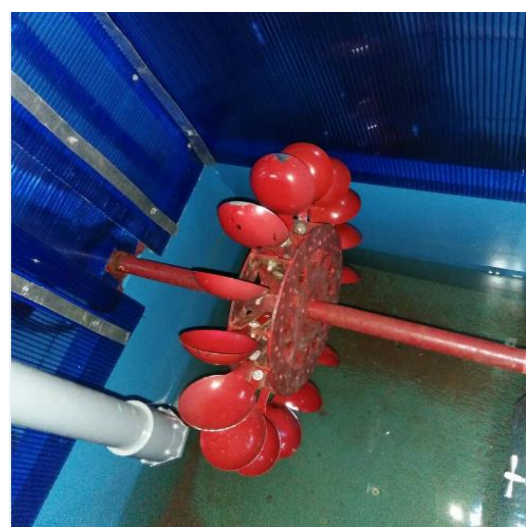

Gambar 5. Sudu sendok sayur.

b. Variabel Terkontrol

1. Putaran turbin dikontrol $350 \mathrm{rpm}, 300$ rpm, 250 rpm, 200 rpm, 150 rpm, 100 rpm, $50 \mathrm{rpm}$ dan $0 \mathrm{rpm}$.

2. Jumlah sudu 16 buah.

3. Sudut sudu dikondisikan konstan pada posisi $90^{\circ}$.

4. Ukuran Nosel $1 \frac{1}{2}$ inchi

c. Variabel Terikat

Variabel terikat pada penelitian ini adalah torsi dan daya turbin.

\section{Prosedur Penelitian}

Adapun prosedur pengujian untuk pengambilan data penelitian yaitu sebagai berikut : 
1. Membuat tabel untuk mencatat hasil pengujian.

2. Menyiapkan dan memasang semua instalasi penelitian beserta alat ukur yang digunakan.

3. Memasang nosel ukuran $1 / 2$ inch sesuai dengan variabel bebas yang ditentukan.

4. Melakukan pengujian pertama dengan memasang salah satu bentuk sudu turbin yang telah ditentukan yaitu sudu datar.

5. Pastikan semua kondisi alat dalam keadaan baik, selanjutnya tekan saklar untuk menghidupkan pompa air.

6. Mencatat debit aliran yang tertera pada alat ukur flowmeter.

7. Mengukur putaran poros turbin dengan alat ukur tachometer tanpa beban terlebih dahulu. Selanjutnya mengukur putaran poros turbin dengan beban yang diberikan secara pelan - pelan dengan cara memutar tuas penyetel beban gaya sampai memenuhi putaran yang divariasi (putaran turbin $350 \mathrm{rpm}$, $300 \mathrm{rpm}, 250 \mathrm{rpm}, 200 \mathrm{rpm}, 150 \mathrm{rpm}$, $100 \mathrm{rpm}, 50 \mathrm{rpm}$ dan $0 \mathrm{rpm})$. Kemudian mencatat nilai gaya pada alat ukur neraca pegas setiap variasi pengukuran putaran turbin sampai turbin berhenti berputar.

8. Mengulang langkah _ langkah pengambilan data dari nomor urut keempat sampai dengan no urut ketujuh pada bentuk sudu sudu lengkung, sudu setengah silinder, sudu sendok nasi, dan sudu sendok sayur.

9. Mengolah data penelitian yang didapatkan.

10. Menganalisa data penelitian yang didapatkan untuk mengetahui hubungan antara variabel yang telah ditentukan.

11. Menarik kesimpulan dari hasil penelitian yang dilakukan.

\section{Instalasi Alat Penelitian}

Pada penelitian ini alat pengujian yang digunakan adalah turbin air pelton poros horizontal yang instalasi dan pembuatannya dilakukan dilaboratorium Teknik Mesin Universitas Trunajaya Bontang dan bengkel di wilayah Kota Bontang. Desain instalasi penelitian ditunjukkan pada gambar 6 .

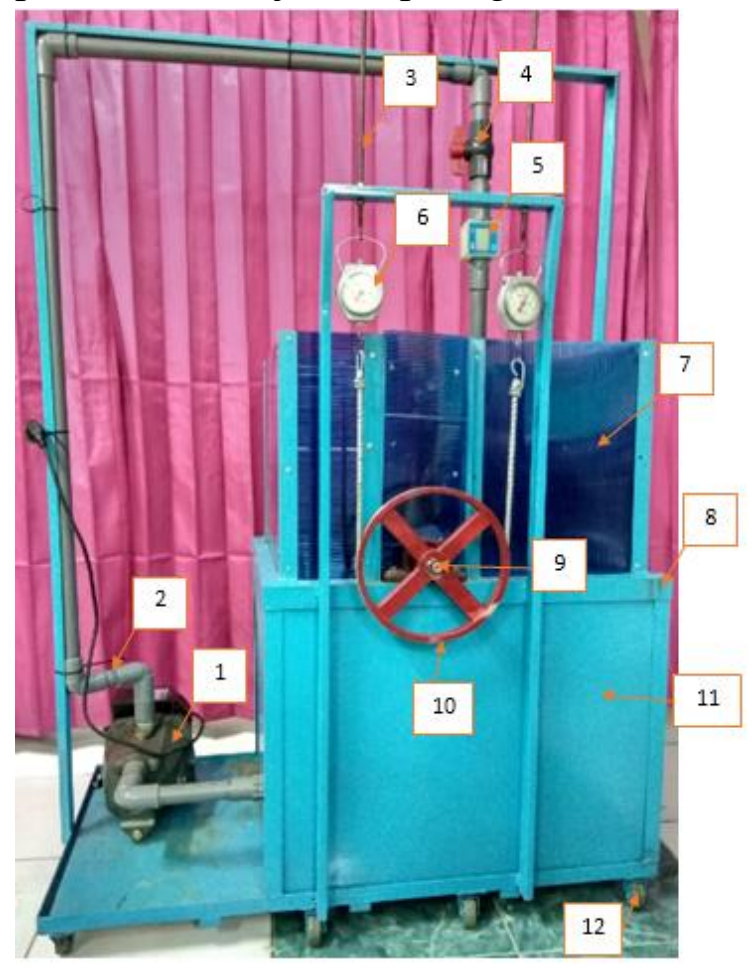

Gambar 6. Desain Instalasi Penelitian.

Keterangan gambar instalasi penelitian turbin air :

1. Pompa air

2. Pipa PVC ukuran 1 inchi

3. Tuas Neraca Pegas

4. Katup

5. Flowmeter

6. Neraca Pegas

7. Rumah Turbin

8. Rangka Istalasi Turbin

9. Poros Turbin

10. Pully

11. Bak Penampung Air

12. Roda Istalasi Turbin 


\section{Hasil dan Pembahasan}

\section{Data Hasil Penelitian}

Penelitian dengan melakukan pengujian terhadap turbin air kampus Universitas Trunajaya Bontang. Pengujian ini dilakukan untuk mendapatkan data putaran (n), gaya (F) dengan posisi komponen tersebut sebagaimana ditunjukan pada gambar 7

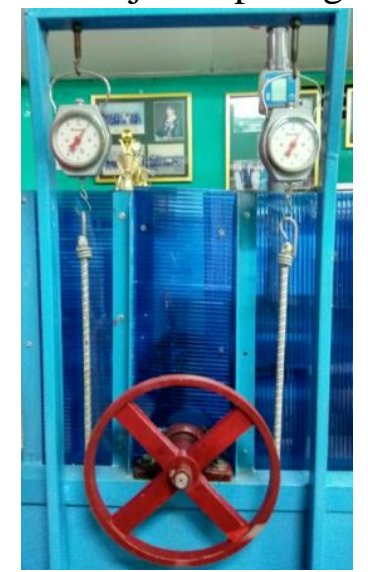

Gambar 7. Desain alat ukur prony (torsi).

Pada penelitian ini dilakukan pengujian terhadap instalasi turbin dengan beberapa bentuk sudu turbin dimana nilai penunjukkan jarum skala putar dari kedua alat ukur neraca pegas merupakan jumlah gaya $\left(\sum \mathrm{F}\right)$ seperti ditunjukkan pada gambar 7, dan data putaran turbin (rpm) didapatkan dengan menggunakan tachometer, dan jari jari pully diukur menggunakan penggaris sehingga diperoleh data penelitian seperti ditunjukkan pada tabel 1 sampai tabel 5 berikut ini :

Tabel 1. Data pengujian bentuk sudu datar

\begin{tabular}{|c|c|c|}
\hline $\begin{array}{c}\text { Jari - jari pully } \\
\mathrm{r}(\mathrm{m})\end{array}$ & $\begin{array}{c}\text { Putaran } \\
\mathrm{n}(\mathrm{rpm})\end{array}$ & $\begin{array}{c}\text { Jumlah gaya } \\
\Sigma \mathrm{F}(\mathrm{Nm})\end{array}$ \\
\hline 0.15 & 317 & 0.0 \\
\hline 0.15 & 300 & 0.0 \\
\hline 0.15 & 250 & 0.1 \\
\hline 0.15 & 200 & 0.2 \\
\hline 0.15 & 150 & 0.3 \\
\hline 0.15 & 100 & 0.5 \\
\hline 0.15 & 50 & 0.6 \\
\hline 0.15 & 0 & 0.9 \\
\hline
\end{tabular}

Tabel 2. Data pengujian sudu lengkung

\begin{tabular}{|c|c|c|}
\hline $\begin{array}{c}\text { Jari - jari pully } \\
\mathrm{r}(\mathrm{m})\end{array}$ & $\begin{array}{c}\text { Putaran } \\
\mathrm{n}(\mathrm{rpm})\end{array}$ & $\begin{array}{c}\text { Jumlah gaya } \\
\Sigma \mathrm{F}(\mathrm{Nm})\end{array}$ \\
\hline 0.15 & 342 & 0.0 \\
\hline 0.15 & 300 & 0.7 \\
\hline 0.15 & 250 & 0.9 \\
\hline 0.15 & 200 & 1.3 \\
\hline 0.15 & 150 & 1.7 \\
\hline 0.15 & 100 & 1.9 \\
\hline 0.15 & 50 & 2.2 \\
\hline 0.15 & 0 & 2.4 \\
\hline
\end{tabular}

Tabel 3. Data pengujian sudu sendok nasi

\begin{tabular}{|c|c|c|}
\hline $\begin{array}{c}\text { Jari - jari pully } \\
\mathrm{r}(\mathrm{m})\end{array}$ & $\begin{array}{c}\text { Putaran } \\
\mathrm{n}(\mathrm{rpm})\end{array}$ & $\begin{array}{c}\text { Jumlah gaya } \\
\Sigma \mathrm{F}(\mathrm{Nm})\end{array}$ \\
\hline 0.15 & 362 & 0.0 \\
\hline 0.15 & 350 & 0.3 \\
\hline 0.15 & 300 & 0.7 \\
\hline 0.15 & 250 & 1.2 \\
\hline 0.15 & 200 & 1.6 \\
\hline 0.15 & 150 & 1.8 \\
\hline 0.15 & 100 & 2.0 \\
\hline 0.15 & 50 & 2.4 \\
\hline 0.15 & 0 & 2.5 \\
\hline
\end{tabular}

Tabel 4. Data pengujian sudu setengah silinder

\begin{tabular}{|c|c|c|}
\hline $\begin{array}{c}\text { Jari - jari pully } \\
\mathrm{r}(\mathrm{m})\end{array}$ & $\begin{array}{c}\text { Putaran } \\
\mathrm{n}(\mathrm{rpm})\end{array}$ & $\begin{array}{c}\text { Jumlah gaya } \\
\Sigma \mathrm{F}(\mathrm{Nm})\end{array}$ \\
\hline 0.15 & 316 & 0.0 \\
\hline 0.15 & 300 & 0.1 \\
\hline 0.15 & 250 & 0.9 \\
\hline 0.15 & 200 & 1.1 \\
\hline 0.15 & 150 & 1.6 \\
\hline 0.15 & 100 & 1.9 \\
\hline 0.15 & 50 & 2.3 \\
\hline 0.15 & 0 & 2.8 \\
\hline
\end{tabular}


Tabel 5. Data pengujian sudu sendok sayur

\begin{tabular}{|c|c|c|}
\hline $\begin{array}{c}\text { Jari - jari pully } \\
\mathrm{r}(\mathrm{m})\end{array}$ & $\begin{array}{c}\text { Putaran } \\
\mathrm{n}(\mathrm{rpm})\end{array}$ & $\begin{array}{c}\text { Jumlah gaya } \\
\Sigma \mathrm{F}(\mathrm{Nm})\end{array}$ \\
\hline 0.15 & 395 & 0.0 \\
\hline 0.15 & 350 & 1.0 \\
\hline 0.15 & 300 & 1.1 \\
\hline 0.15 & 240 & 1.5 \\
\hline 0.15 & 200 & 1.7 \\
\hline 0.15 & 150 & 2.0 \\
\hline 0.15 & 100 & 2.6 \\
\hline 0.15 & 50 & 2.8 \\
\hline 0.15 & 0 & 3.7 \\
\hline
\end{tabular}

Berdasarkan tabel 1 sampai tabel 5. Data hasil penelitian bahwa gaya pengereman yang terjadi pada setiap bentuk sudu berbeda - beda walaupun putarannya dikondisikan sama.

\section{Hasil Pengolahan Data}

Dari data pengujian yang dilakukan tersebut kemudian dilakukan pengolahan atau perhitungan untuk mendapatkan nilai daya turbin. Pada penelitian ini teknik analisa data menggunakan teknik deskriptif berdasarkan hasil penelitian yang dilakukan. Data yang diperoleh dari hasil penelitian kemudian dianalisis menggunakan rumus terapan untuk mendapatkan nilai torsi dan daya turbin, selanjutnya data akan disajikan dalam bentuk grafik dengan bantuan Microsoft Office Excel untuk menampilkan grafik torsi turbin dan daya turbin terhadap putaran turbin dari hubungan antara variasi bentuk sudu yang diteliti.

Tabel 6. Hasil pengolahan data torsi turbin pada semua bentuk sudu

\begin{tabular}{|c|c|c|c|c|c|}
\hline \multirow{2}{*}{$\begin{array}{c}\text { Putaran, } \\
\text { n (rpm) }\end{array}$} & \multicolumn{5}{|c|}{ Torsi Turbin, T (Nm) } \\
\cline { 2 - 6 } & $\begin{array}{c}\text { Sudu } \\
\text { Datar }\end{array}$ & $\begin{array}{c}\text { Sudu } \\
\text { Lengkung }\end{array}$ & $\begin{array}{c}\text { Sudu } \\
\text { Sendok } \\
\text { Nasi }\end{array}$ & $\begin{array}{c}\text { Sudu } \\
\text { Setengah } \\
\text { Silinder }\end{array}$ & $\begin{array}{c}\text { Sudu } \\
\text { Sendok } \\
\text { Sayur }\end{array}$ \\
\hline 350 & & & 0.045 & & 0.15 \\
\hline 300 & 0.015 & 0.105 & 0.105 & 0.015 & 0.165 \\
\hline 250 & 0.09 & 0.135 & 0.18 & 0.135 & 0.225 \\
\hline 200 & 0.15 & 0.195 & 0.24 & 0.165 & 0.255 \\
\hline 150 & 0.21 & 0.255 & 0.27 & 0.24 & 0.3 \\
\hline 100 & 0.3 & 0.285 & 0.3 & 0.285 & 0.39 \\
\hline 50 & 0.375 & 0.33 & 0.36 & 0.345 & 0.42 \\
\hline 0 & 0.435 & 0.36 & 0.375 & 0.42 & 0.555 \\
\hline
\end{tabular}

\section{Pembahasan Hasil Penelitian}

Dari data tabel 6 tersebut kemudian dijadikan dalam bentuk grafik, pembuatan grafik bertujuan untuk melihat fenomena trending grafik torsi turbin yang dilakukan dengan menggunakan bantuan Microsoft Office Excel . Hubungan antara torsi dan putaran pada bentuk sudu yang diteliti seperti ditunjukkan gambar 8 .

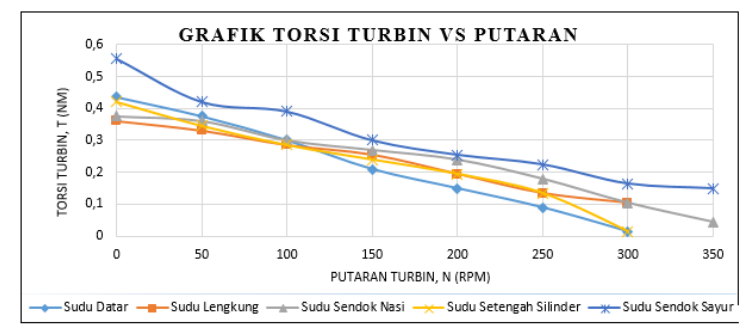

Gambar 8. Grafik hubungan torsi turbin terhadap putaran turbin

Berdasarkan hasil pengolahan data dan gambar 8 yaitu grafik hubungan torsi turbin dan putaran turbin terhadap bentuk sudu turbin terlihat bahwa dengan bertambahnya putaran turbin maka torsi turbin yang dihasilkan menurun secara proposional, hal ini terjadi karena pada proses pengambilan data putaran dikondisikan nilainya berdasarkan gaya pengereman dan gaya pengereman inilah yang mempengaruhi nilai torsi turbin. Pada penelitian ini diberikan lima variasi bentuk sudu yaitu sudu datar, sudu lengkung, sudu sendok nasi, sudu setengah silinder dan sudu sendok sayur. Berdasarkan gambar 8 torsi turbin maksimum terjadi pada sudu sendok sayur, kemudian torsi kedua pada sudu datar, torsi ke tiga pada sudu setengah silinder, torsi keempat pada sudu sendok nasi, dan torsi terendah terjadi pada sudu lengkung.

Pada bentuk sudu datar didapat torsi turbin maksimum terjadi pada putaran terendah dengan nilai torsi turbin sebesar $0,435 \mathrm{Nm}$, sedangkan torsi turbin terendah terjadi pada putaran tinggi dengan nilai torsi turbin sebesar $0.015 \mathrm{Nm}$.

Pada bentuk sudu lengkung didapat torsi turbin maksimum terjadi pada putaran 
terendah dengan nilai torsi turbin sebesar $0,36 \mathrm{Nm}$, sedangkan torsi turbin terendah terjadi pada putaran tinggi dengan nilai torsi turbin sebesar 0,105 Nm.

Pada bentuk sudu sendok nasi didapat torsi turbin maksimum terjadi pada putaran terendah dengan nilai torsi turbin sebesar $0,375 \mathrm{Nm}$, sedangkan torsi turbin terendah terjadi pada putaran tinggi dengan nilai torsi turbin sebesar 0,045 Nm.

Pada bentuk sudu setengah silinder didapat torsi turbin maksimum terjadi pada putaran terendah dengan nilai torsi turbin sebesar 0,42 Nm, sedangkan torsi turbin terendah terjadi pada putaran tinggi dengan nilai torsi turbin sebesar $0,015 \mathrm{Nm}$.

Pada bentuk sudu sendok sayur didapat torsi turbin maksimum terjadi pada putaran terendah dengan nilai torsi turbin sebesar 0,555 Nm, sedangkan torsi turbin terendah terjadi pada putaran tinggi dengan nilai torsi turbin sebesar $0,15 \mathrm{Nm}$.

Tabel 6. Hasil pengolahan data daya turbin pada semua bentuk sudu

\begin{tabular}{|l|l|l|l|l|l|}
\hline \multirow{2}{*}{$\begin{array}{l}\text { Putaran, } \\
\text { n (rpm) }\end{array}$} & \multicolumn{5}{|l|}{ Daya Turbin, Pt (Watt) } \\
\cline { 2 - 6 } & $\begin{array}{l}\text { Sudu } \\
\text { Datar }\end{array}$ & $\begin{array}{l}\text { Sudu } \\
\text { Lengkung }\end{array}$ & $\begin{array}{l}\text { Sudu } \\
\text { Sendok } \\
\text { Nasi }\end{array}$ & $\begin{array}{l}\text { Sudu } \\
\text { Setengah } \\
\text { Silinder }\end{array}$ & $\begin{array}{l}\text { Sudu } \\
\text { Sendok } \\
\text { Sayur }\end{array}$ \\
\hline 350 & & & 1.6485 & & 5.495 \\
\hline 300 & 0.471 & 3.297 & 3.297 & 0.471 & 5.181 \\
\hline 250 & 2.355 & 3.5325 & 4.71 & 3.5325 & 5.652 \\
\hline 200 & 3.14 & 4.082 & 5.024 & 4.082 & 5.338 \\
\hline 150 & 3.297 & 4.0035 & 4.239 & 3.768 & 4.71 \\
\hline 100 & 3.14 & 2.983 & 3.14 & 2.983 & 4.082 \\
\hline 50 & 1.9625 & 1.727 & 1.884 & 1.8055 & 2.198 \\
\hline 0 & 0 & 0 & 0 & 0 & 0 \\
\hline
\end{tabular}

Hasil pengolahan data pengujian pada semua bentuk sudu turbin untuk mendapatkan nilai daya turbin seperti ditunjukkan pada tabel 7, Dari data tabel 7 tersebut kemudian dijadikan dalam bentuk grafik daya turbin. Hubungan antara daya dan putaran pada variasi bentuk sudu seperti ditunjukkan gambar 9.

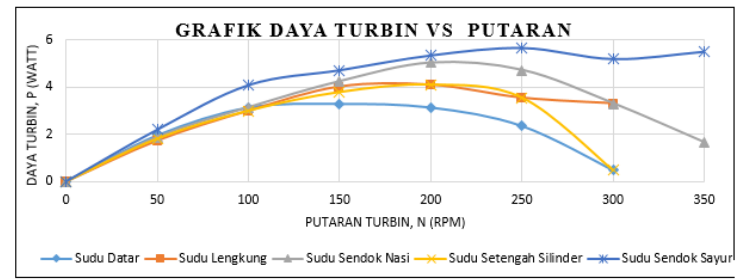

Gambar 9. Grafik hubungan daya turbin terhadap putaran turbin pada variasi bentuk sudu

Pada penelitian ini diberikan lima variasi bentuk sudu yaitu sudu datar, sudu lengkung, sudu sendok nasi, sudu setengah silinder dan sudu sendok sayur. Daya turbin sangat tergantung pada besarnya torsi dan kecepatan anguler, sedangkan besarnya kecepatan anguler dipengaruhi oleh putaran turbin yang didapatkan dengan menggunakan tachometer dan besarnya nilai torsi dipengaruhi oleh nilai gaya yang didapat dari neraca pegas. Berdasarkan gambar 9 daya turbin maksimum terjadi pada sudu sendok sayur, kemudian daya turbin kedua pada sudu sendok nasi, daya turbin ketiga terjadi pada sudu lengkung dan pada sudu setengah silinder, sedangkan daya turbin terendah terjadi pada sudu datar.

Pada bentuk sudu datar didapat daya turbin maksimum terjadi pada putaran 150 rpm dengan nilai daya turbin sebesar 3,297 Watt, sedangkan daya turbin terendah terjadi pada rpm 300 dengan nilai sebesar 0,471 Watt.

Pada bentuk sudu lengkung daya turbin maksimum terjadi pada putaran $200 \mathrm{rpm}$ dengan nilai daya turbin sebesar 4,082 Watt, sedangkan daya turbin terendah terjadi pada rpm 50 dengan nilai sebesar 1,727 Watt.

Pada bentuk sudu sendok nasi daya turbin maksimum terjadi pada putaran 200 rpm dengan nilai daya turbin sebesar 5,024 Watt, sedangkan daya turbin terendah terjadi pada rpm 350 dengan nilai sebesar 1,649 Watt.

Pada bentuk sudu setengah silinder daya turbin maksimum terjadi pada putaran 200 
rpm dengan nilai daya turbin sebesar 4,082 Watt, sedangkan daya turbin terendah terjadi pada rpm 300 dengan nilai sebesar 0,471 Watt.

Pada bentuk sudu sendok sayur daya turbin maksimum terjadi pada putaran 250 rpm dengan nilai daya turbin sebesar 5,652 Watt, sedangkan daya turbin terendah terjadi pada rpm 50 dengan nilai sebesar 2.198 Watt.

\section{Kesimpulan}

Hasil penelitian menunjukan adanya pengaruh bentuk sudu terhadap torsi dan daya turbin air pelton, sehingga dapat disimpulkan bahwa :

1. Torsi turbin maksimum terjadi pada sudu sendok sayur dengan nilai sebesar 0,555 Nm, kemudian torsi kedua pada sudu datar dengan nilai sebesar 0,435 $\mathrm{Nm}$, torsi ke tiga pada sudu setengah silinder dengan nilai sebesar $0,420 \mathrm{Nm}$, torsi keempat pada sudu sendok nasi dengan nilai sebesar $0,375 \mathrm{Nm}$, dan torsi terendah terjadi pada sudu lengkung dengan nilai sebesar $0,360 \mathrm{Nm}$.

2. Daya turbin maksimum terjadi pada sudu sendok sayur dengan nilai sebesar 5,652 Watt, kemudian daya turbin tertinggi kedua terjadi pada sudu sendok nasi nilai sebesar 5,024 Watt, urutan daya turbin tertinggi ketiga terjadi pada sudu lengkung dan pada sudu setengah silinder nilai sebesar 4,082 Watt, sedangkan daya turbin terendah terjadi pada sudu datar nilai sebesar 3,297 Watt.

\section{Daftar Pustaka}

[1]. Arismunandar., W. (2004). Penggerak mula turbin, edisi kitiga ITB, Bandung.

[2]. Hamidi. Supandi. Dan Rohermanto, A, (2006). “ Rancang Bangun Model Turbin Pelton Mini Sebagai Media Simulasi/Praktikum Matakuliah
Konversi Energi dan Mekanika Fluida" Jurnal Ilmiah Semesta Teknika, Jurusan Teknik Mesin Politeknik Negeri Pontianak.

[3]. Prasetyo, G. dan Dharma, U. S, (2012) Pengaruh Perubahan Laju Aliran Terhadap Tekanan dan Jenis Aliran yang Terjadi Pada Alat Uji Praktikum Mekanika Fluida. Jurnal Turbo. Program Studi Teknik Mesin Fakultas Teknik Universitas Muhammadiyah Metro. Lampung.

[4]. Susatyo, A. dan Hakim, L (2003) perancangan turbin pelton. Prosiding Seminar Nasional tanggal 29 - 30 Juni, pusat penelitian informatika - LIPI. Bandung

[5]. Yani. A, Mihdar dan Erianto. R (2016) "Pengaruh variasi bentuk sudu terhadap Kinerja Air turbin kinetik" ( Sebagai Pembangkit Listrik Daerah Pedesaan) Jurnal Turbo. Jurusan Teknik Mesin Fakultas Teknik Universitas Trunajaya Bontang - Kaltim.

[6]. Thobari. A, Mustaqim, dan Wibowo H, (2013) "Analisa Pengaruh Sudut Keluar Sudu Terhadap Putaran Turbin Pelton" Jurnal ilmiah Faculty of Engineering, Universitas Pancasakti Tegal. 